\title{
Morphological features of five-rooted maxillary second molar evaluated by spiral CT
}

\author{
Radhika Muppa, ${ }^{1}$ Karunakar Parupalli, ${ }^{2}$ Pratej Kiran Kanumuri, ${ }^{3}$ Ravi Varma Dandu ${ }^{4}$
}

${ }^{1}$ Department of Pedodontics and Preventive Dentistry, Panineeya Mahavidyalaya Institute of Dental Sciences and Research Centre,

Hyderabad, Telangana, India ${ }^{2}$ Department of Conservative and Endodontics, Panineeya Mahavidyalaya Institute of

Dental Sciences and Research Centre, Hyderabad, Telangana, India

${ }^{3}$ Panineeya Institute of Dental Sciences and Hospital, Hyderabad, Telangana, India ${ }^{4}$ Krishna Institute of Medical Sciences College of Nursing, Secunderabad, Telangana, India

Correspondence to Dr Pratej Kiran Kanumuri, pratejkiran@gmail.com

Accepted 25 January 2017

CrossMark

To cite: Muppa R, Parupalli K, Kanumuri PK, et al. BMJ Case Rep Published online: [please include Day Month Year] doi:10.1136/bcr-2016217852

\section{DESCRIPTION}

The anatomical characteristics of permanent maxillary molars generally include three roots-one palatal and two buccal, each root with one root canal. The present case report aims at discussing a rare anatomy of the maxillary second molar with five roots.

The complexities and variations of the roots and their canal system present a constant challenge for diagnosis and successful endodontic treatment. ${ }^{1}$ Newer technologies like spiral CT can also be used to study root canal morphology in complicated cases. Since the subject of study was an extracted tooth, the concern regarding radiation was not there. The use of multislice CT and 3D reconstruction techniques help in understanding the possible anatomical aberrations of maxillary molars and emphasise their role in the confirmatory diagnosis.

A female patient aged 19 years reported to our clinic with pain in the upper right posterior region of the jaw since 3 months. Her medical history was not significant. On clinical examination, deep carious lesion of the right second maxillary molar (17 FDI System) was seen. Owing to financial constraints, the patient and the family were not willing for any investigation or treatment. Extraction of the tooth was performed with patient's consent.

The maxillary second molar was found with five roots mesiobuccal, distobuccal and three palatal roots. The presence of five roots gave us an interest to study the internal and external morphology of the tooth. The tooth was examined under a micro spiral CT and an endomicroscope for internal

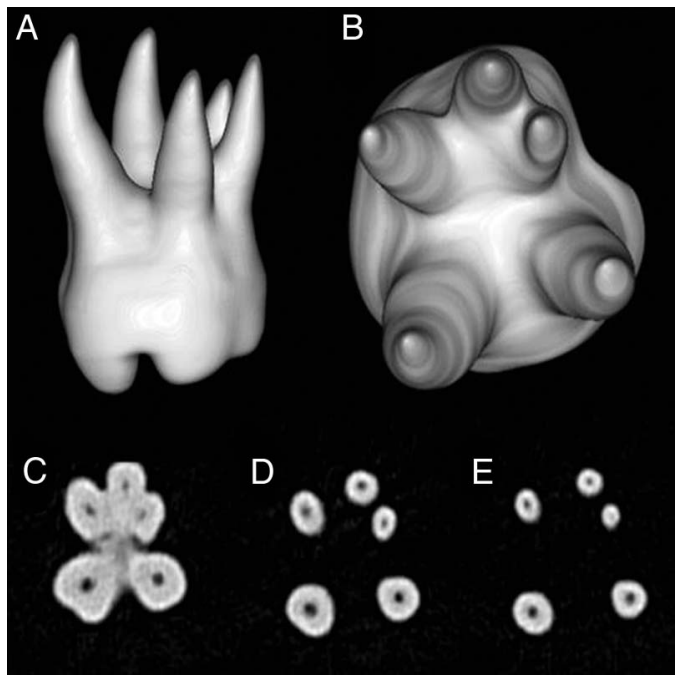

Figure 1 A multipart image containing a series of axial images at different levels showing in cross-section the course of root canals.

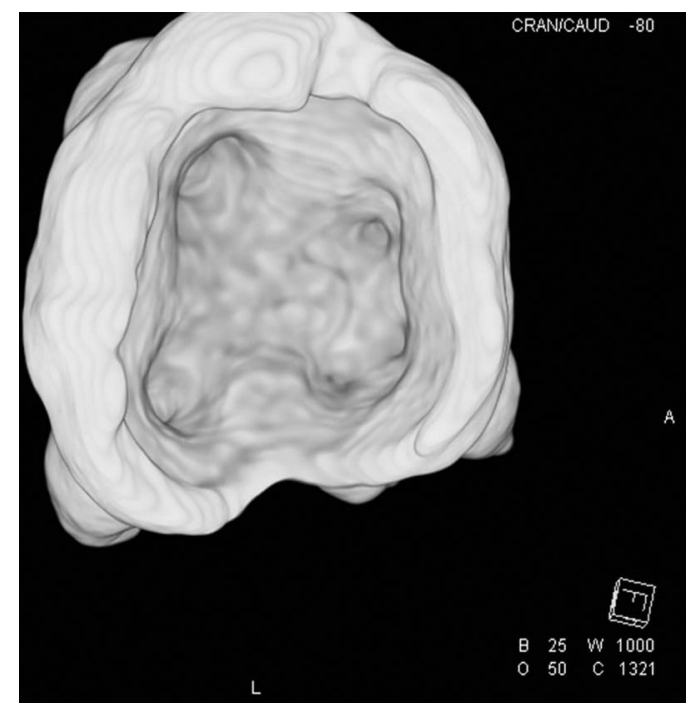

Figure 2 Axial view showing the root canal orifice.

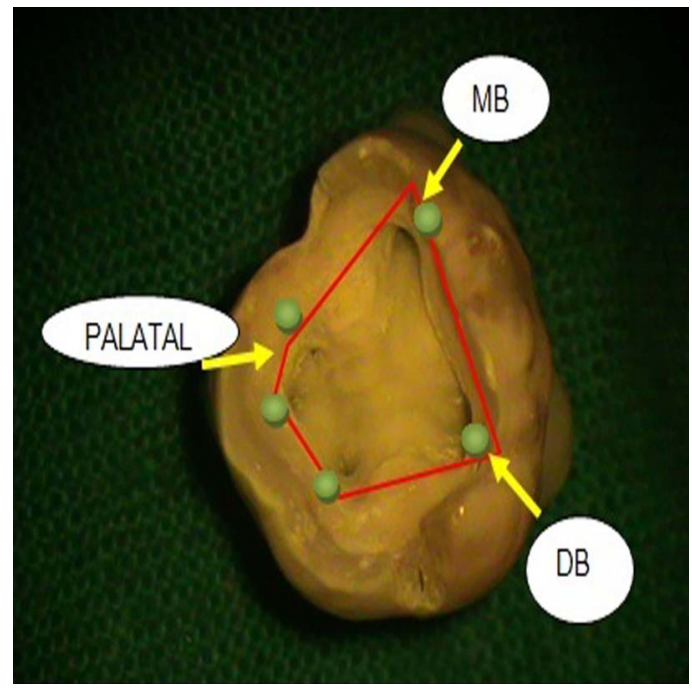

Figure 3 Pulpal floor showing five root canal orifices.

anatomy (figure 1). Spiral CT imaging of the extracted tooth was performed on a 128-slice dualsource CT scanner (SOMATOM Definition; Siemens, Erlangen, Germany). Since it is an ex vivo study, CT scan parameters were as follows: detector collimation, $16 \times 0.3 \mathrm{~mm}$; gantry rotation time, $1 \mathrm{~s}$; tube voltage, $120 \mathrm{kV}$; effective $\mathrm{mAs}, 180 \mathrm{mAs}$; pitch, 0.6; image reconstruction, $0.4 \mathrm{~mm}$ effective slice width at 0.4 increment; $512 \times 512$ pixel matrix; convolution kernel, very sharp U75u. On a dedicated external workstation, 3D volumerendering reconstruction and axial reformations of the tooth were made (figure 2). 
A new variant of the permanent second maxillary molar with five separate roots and canals, mesiobuccal root, distobuccal root with a single canal and three individual palatal roots, namely

\section{Learning points}

- A rare anatomical configuration of the maxillary second molar with five roots has been reported.

- The use of latest reconstruction scans can aid in diagnosis and help in treating complicated root canal morphologies. midpalatal, mesiopalatal and distopalatal, with their own canals, has so far not been reported in the literature (figure 3).

Contributors RM performed the case. KP prepared the manuscript. PKK prepared the manuscript. RVD helps in taking spiral CT scan.

Competing interests None declared.

Patient consent Obtained.

Provenance and peer review Not commissioned; externally peer reviewed.

\section{REFERENCE}

1 Cicek E, Ozsezer EO, Ozsevik $\mathrm{S}$. The root canal treatment in maxillary and mandibular molars with five root canals. Two case reports with two years follow up. Int I Case Rep Images 2012;3:11-15.

Copyright 2017 BMJ Publishing Group. All rights reserved. For permission to reuse any of this content visit

http://group.bmj.com/group/rights-licensing/permissions.

BMJ Case Report Fellows may re-use this article for personal use and teaching without any further permission.

Become a Fellow of BMJ Case Reports today and you can:

- Submit as many cases as you like

- Enjoy fast sympathetic peer review and rapid publication of accepted articles

- Access all the published articles

- Re-use any of the published material for personal use and teaching without further permission

For information on Institutional Fellowships contact consortiasales@bmjgroup.com

Visit casereports.bmj.com for more articles like this and to become a Fellow 